\title{
MEDICAL PROTECTION, A KEY ELEMENT IN ENSURING THE CONTINUITY OF THE MILITARY CENTERS ACTIVITIES, UNDER THE CONSTANT PRESSURE OF CONTAMINATION WITH THE SARS-CoV-2 VIRUS
}

\author{
Lt.Col. Ionel COTOARBĂ, PhD Candidate*
}

\begin{abstract}
In the event of a pandemic, the priorities for any commander must be focused on protecting their own personnel, maintaining combat capability and carrying out the missions. The personnel protection measures are implemented in a unitary and gradual conception depending on the pandemic evolution in the area of responsibility. The appearance of increasingly contagious viruses and the promotion of their rapid spread globally through the diversity and complexity of land, air and naval transport, forces us to reconsider our position on the following issues: training and recruitment of staff; making stocks; adaptation of protection measures, in particular of personnel; optimization of operating procedures based on clearly defined principles.
\end{abstract}

Keywords: military centers; planning; personnel protection; protection measures; circuits; risk areas.

After the declaration by the World Health Organization in March 2020 of the COVID19 pandemic as a result of the sudden spread of infections caused by the SARS-CoV-2 virus and the declaration of a state of emergency throughout Romania starting with $16^{\text {th }}$ of March $2020^{1}$, every institution in the national security system, public order and national security has gone through difficult moments, understanding more or less the necessity to implement the minimum measures imposed by governmental and local authorities.

Regarding the aforementioned issue, at the military units' level, there was rightly felt a necessity to coordinate structures through orders, instructions, directives, realistic messages to present the situation at the global, regional, national and local level.

In my opinion, in the absence of coherent standard operating procedures, the commanders/ managers applied the recommended measures in their own interpretation. For this reason, but also as a result of our success, at least so far $^{2}$, to communicate zero cases of infection with the new virus, we intend to present the actions, activities and measures taken at the Argeș District Military

\footnotetext{
*Argeș District Military Center

e-mail: ionelcotoarba@yahoo.com
}

Center for analysis and also, as a guide of conduct in such situations.

Many claim that we were lucky, others say that we are too exaggerated, but we say that in addition to a gram of chance, our success was based on the observance of some principles: anticipation; adaptability; flexibility in applying measures; gradualism; economy of forces and means; concentration of effort; restrictive mobility (establishing priorities) ${ }^{3}$.

Even from the specifics of military centers to interact permanently with reservists, potential candidates during the recruitment process, countless actions of direct promotion of the institution in schools, military units, through stands organized at local events, interaction with war veterans through visits through the "visit the veterans at their homes"4 program, the permanent collaboration with the police stations, the local public administration authorities, the economic operators and the structures from the area of responsibility, derived the bringing to the forefront of the issue.

\section{Establishment of risk areas and circuits}

From the beginning, I must mention that before the pandemic, we were using waiting rooms for the public relations activities/events. The risk was assigned based on the assumption that its own staff and those outside the institution receive adequate protection. 
Our conception for establishing the risk areas was based on the physical delimitation of some areas depending on the threat, the potential dangers and vulnerabilities.

The red area represents the visible space to be limited and marked accordingly, where the initial interaction with an outside person takes place. In this perimeter the triage is made: the minor interrogation regarding the problem in question, the completion of the COVID-19 questionnaire, the body temperature measurement and the instruction regarding the access to the counter or the information-recruitment office are performed.

This area is classified as a high risk area, it can be an office where a contaminated person has been identified and which, prior to the contamination, was a green or yellow area.

The yellow area is outlined based on the spaces in which it relates to the public. The access to these spaces is made with the cumulative observance of some conditions: triage performed, protection measures in operation (wearing a mask, decontamination of hands/wearing surgical gloves, shoes decontamination, social distancing and flow circuit compliance). Daily, these areas are ventilated and decontaminated with ultraviolet rays and solutions, according to the product specifications.

The green area includes all the other spaces that have not been assigned the color yellow or green. Usually, the staff works in this area. The staff wears masks, the surfaces are decontaminated daily, including the communication equipment. When suspicions arise, ultraviolet decontamination can be conducted, but this type of action is focused on the yellow area.

At the same time, we established three circuits without intersection, focused strictly on the protection of our own personnel and the one we interacted afterwards, with the mention that the wearing of the mask was established from the beginning, by anticipating the evolution at the national level.

The routes established in the first circuit are addressed to our personnel, who at the beginning of the program, after parking the vehicles inside the unit, are tested for fever and questioned at the epidemiological triage performed by the designated person.

Then, they decontaminate the hands and shoes, and after signing the special register on the absence of AURTI $^{5}$ or other symptoms that fall within the case definition of the disease (fever, cough, dysphagia, headache, rhinorrhea, etc.) Their access to the program is allowed. In case of manifestation/ occurrence of symptoms, the person is immediately removed and sent for investigation, following the procedures established at national level.

That person has the obligation to inform the medical decision immediately and to provide a certificate stating that he or she is not at risk of being infected with the SARS-CoV-2 virus, sick leave or other health-related documents in order to take action.

We established the second circuit for public relations on issues concerning the military evidence. In this regard, the special space is designed to ensure social distance by establishing safety limits, and for proper communication with the petitioner a transparent protective panel has been installed.

Each petitioner that presents himself at the military center headquarters, after thermometry, is escorted and guided to complete a COVID-19 evaluation questionnaire established by our own operational procedure. Before entering in to the waiting room, the person is invited to carry out decontamination with hands and shoes sanitizers.

Subsequently, he will wait in the area specially marked to ensure social distancing, until he is picked up by the service staff at the counter.

The duty and the administrative staff were trained to disinfect the work surfaces after interacting with each person.

The third circuit and set of measures targets the candidates and the staff in the informationrecruitment office. The arrival of the candidates at the military center headquarter, for their orientation or for the completion of the candidate file, is made through an appointment, in order to ensure social distance in the workrooms and in compliance with the restrictions established at the national level.

The candidates are constantly guided to follow the pre-established and properly marked itineraries. Before entering the hall of the informationrecruitment office, the candidate and his companion decontaminate their shoes and hands with alcoholbased sanitizer or by washing with soap and water for 20-40 seconds. After completing the activity with each candidate, the recruiting staff performs the disinfection of the work/contact surfaces with materials and sanitizers provided by logistic staff. 
The spaces designated for the service at the counter and the office were classified as yellow areas based on two main aspects the public and the desire to achieve a clear separation of the circuits.

In accordance with the approved daily work schedule, the decontamination with ultraviolet rays of the spaces designated for the execution of the service at the counter and for relations with the candidates is carried out daily.

\section{Staff protection}

In order to make the protection actions of our own personnel more efficient we permanently focused on regular training, the provision of protective equipment and materials, the completion of stocks, the adaptation and improvement of the ordered protection measures.

Through regular training, we believe that we have succeeded in forming a noteworthy behavior, permanently based on dialogue, mutual trust, credible information and substantiated statements. The processing of compliance with protection measures, social distancing, wearing a protective mask, washing hands, disinfecting work surfaces, ventilating the premises, at the risk of transmitting the SARS-CoV-2 virus, even from asymptomatic persons was also performed by applying informative, explicit materials placed at the epidemiological triage point, at the public relations desk, in the restrooms and on each level.

At the same time, through the presence of the doctor and the psychologist that we are assigned to, we managed to maintain the staff's morale at a high level, verified by the specific tests applied even in the big trouble and identification of solutions to solve a community contamination at national level. The dialogue with employees about the measures taken, the constant pressure of contamination, can lead to the identification of people who need psychosocial support.

Also, a considerable percentage of our success is largely attributed to the implementation of orders received from higher echelons, which have permanently perceived solving the problem as a joint effort. The establishment of the shift work schedule or staggered shifts, but also the freedom of the commanders to adapt their measures, helped to avoid staff depletion.

For example, when achieving tasks where a sustained effort was required, we tried, as much as possible, to avoid merging staff at the institution, by sending teams in several directions in the area of responsibility, managing to achieve the planned objectives. Such actions had a double purpose, on the one hand to reduce the possible inherent intrapersonal tensions, generated by the stress that you can be contaminated by the one you interact with daily, and on the other hand the mental improvement by extraction from the oppressive bureaucratic environment, risk taken, awareness that you may be less exposed in this way.

The results of the measures taken were reflected in the health of the staff, which favored the execution of rest leave in full, but according to a rule derived from dialogue and analysis by which the person concerned had a recreation period of about one week, followed by spending the next 14 days in their home /safe area, during which time they could realize a possible contamination.

Breaking stereotypes may have been the most important element in our success to avoid infection with the new virus, managing to interact directly with over 160 economic operators, performing actions to promote the military profession in all educational institutions in the area of responsibility (206 middle schools and high schools), relating to about 2000 candidates, over 700 petitioners and to honor our war veterans as we know best, through the program "visit the veterans at their homes" with representatives of The Quality of Life Directorate and representative associations in the county.

The success in completing with military and material resources some military structures was the result of the synergistic actions of the own personnel, of the completed structure and last but not least of the personnel from the police structures.

Of course, these results are based on the remarkable inter-institutional collaboration relations with the local public authorities and the structures of the national system of security, public order and national security, consolidated during the over 50 years of experience.

However, it should be noted that depending on the incidence of cases at the local level, some activities were suspended or rescheduled when the situation was favorable, and others such as analysis, gatherings, including the preparation of local elected officials and economic operators took place by mail or via online ${ }^{6}$. 
The continuity of the activity of the military center was supported by the inspections and internal controls, also those of the upper echelons through which a complete radiography was performed, tasks and new protection measures were outlined.

\section{Specific protection measures}

For every manager, undertaking and applying all measures of prevention and protection against contamination with the SARS-CoV-2 virus must be not only a responsibility but also a moral obligation to minimize occupational risks. Infection of employees can have a negative impact on the performance of tasks, current activities and, implicitly, on the achievement of objectives ${ }^{7}$.

Conclusions from the behavior, characteristics and resistance of viruses to environmental conditions, incubation period, pathogenicity, contagiousness and lethality rate contribute to the adoption of certain measures ${ }^{8}$.

Thus, all the protection measures applied concerned, in particular, the health of staff and, in particular, the gain of time until the discovery of a vaccine.

Among the first measures adopted since the declaration of the pandemic were, in addition to those related to reducing the number of people in offices, those focused on information and training, initially carried out abroad, and later on the electronic training platform COVID-19, where the orders were posted and numerous information materials were received/transmitted.

Here we especially appreciate the constant support of the Directorate of Information and Public Relations within the Ministry of National Defence, which has always managed to give us a comprehensive and realistic picture of the evolution of contamination and some orders, data, statistics and information of interest, thus permanently knowing the share of threats and risks in the disposal area.

The installation of sanitation dispensers in areas easily accessible to staff and visitors, the promotion of a culture of hand washing and regular disinfection of work surfaces, common areas, are considered basic measures, which have led to awareness of the danger among employees, an important aspect in managing the situation.

The most pressing issues were those related to providing the necessary personal protective equipment, biocides, equipment and specific materials. These needs have been prioritized and resolved in a relatively short time with the support of local authorities, the military unit that provides us from a logistical point of view and the upper echelons. From this point, it was only a step in establishing circuits and measures for disinfection and decontamination with solutions or ultraviolet rays.

The realized circuits follow some rules: daily decontamination, before the beginning of the program and whenever there is a suspicion, including with UV rays; controlled access by thermometry, wearing protective equipment (at least a mask), completing the COVID-19 questionnaire, decontamination of hands and shoes; marked routes and information materials for guidance, warning and awareness of the danger; construction of work areas with low risk of infection by reducing the number of the personnel, installation of protection panels, daily ventilation and decontamination, wearing a protective mask.

Ensuring social distancing by tracing the markings, including in the waiting rooms and on the sports base for practical-applicative meetings, assemblies or inspections, was also an effective measure in terms of decongesting crowds in enclosed spaces. This measure was completed with the installation of transparent protection panels in offices, at the counter and in the information and recruitment room. Each recruiter was assigned a personalized work point, personal protective equipment (surgical masks, gloves, visors), materials and solutions for disinfecting work surfaces after each interaction with the candidate.

Considering that RBC decontamination is planned and carried out in order to maintain / restore combat capability, reducing contamination to a negligible risk, so as to ensure the continuity of activities and the accomplishment of missions ${ }^{9}$, the disinfection of outdoor spaces, with a focus on the red zone, was carried out in the first part of the pandemic with the logistic unit support. Subsequently, afterreceiving the specific equipment, by the staff of the administrative structure, through a prior training of its and of the entire staff of own structure.

The activities performed in the area of responsibility were carried out in compliance with measures to prevent contamination with 
SARS-CoV-2 virus, based on careful planning (algorithm establishment, check list, phone calls, clarification messages, reconnaissance, etc.). Several seeminglyelementary rules havecontributed to our success in reporting zero contaminated COVID-19, by reducing the exposure / interaction time with each economic operator, police station, veteran usually less than 15 minutes, to replace protective equipment and perform minimal hand decontamination. The vehicles were equipped with disposable wipes, plastic bags and products needed to disinfect hands and surfaces with which they frequently come into contact.

The phasing of the program, the sequential program (14 working days, 14 recovery days), the provision of workspaces with equipment and materials, the reduction of congestion and through missions performed simultaneously in several directions, the merging of rest periods contributed to ensuring protection of its own staff.

Through protection measures adapted to the specifics of the structure, we managed to gain the necessary time to make the vaccine. Given that all staff want to be vaccinated and that three types of vaccine are approved at EU level, we believe that the war against an unseen enemy will end with the acquisition of immunization as a result of the recall.

The effects of the COVID-19 pandemic and the prospect of the cyclical evolution of the virus oblige us on the one hand to be vigilant and cautious, and on the other hand to continue and develop new protection measures to "increase the capacity to manage such a crisis", especially in terms of increasing the resilience of structures ${ }^{10}$.

\section{Conclusions}

All actions and protective measures applied must be scientifically substantiated, based on relevant analyzes and a rigorous planning process that includes an ongoing assessment of the risks, threats and dangers in the vicinity of the disposal area to identify the best solutions to avoid, limiting and eliminating cases of contamination in the pandemic situation generated by the SARS-CoV-2 virus.

As a conclusion, when a COVID-19 pandemic occurs, stress management, continuous assessment of risks, threats, dangers and vulnerabilities, the identification, adaptation and gradual application of protection measures can be a successful algorithm.
With the information related above, we want to be a starting point for the leaders of military institutions and not only, in managing a situation like the one addressed, maintaining the functionality of the structure, designing and carrying out specific activities.

In a world of overwhelming development of information technology, the establishment of recognized levels of protection, at least at national level, the creation of interinstitutional databases that can be queried about infected people, supplemented by the support of specialists for "understanding how to transmit of the pathogen, the degree of virulence and the lethality of the contamination at local, regional or global level"11 are aspects that can contribute to ensuring adequate protection.

\section{NOTES:}

1 The act signed by the President of Romania, Mr. Klaus Werner Iohannis, regarding the establishment of the state of emergency on the Romanian territory of March 16, 2020.

2 March 4 2021, the date of sending the article for verification and publication in the Bulletin of "Carol I" National Defence University no. 2/2021.

3 *** CBRN protection Field Manual, Bucharest, 2015, 2015, p. 18.

4 The program was initiated by The Quality of Life Directorate within the Ministry of National Defence.

5 Acute upper respiratory tract infection.

6 *** Romanian Government Decision no. 969 of $22^{\text {nd }}$ August 2007 on the organization, conduct and management of training for the defence of persons with managerial responsibilities in the field of public administration, at central and local level, Art. No. 1.

7 https://www.ilo.org/wcmsp5/groups/public, accessed on 22.02.2021.

8 Ion Mitulețu, "Are we ready to deal with a biological crisis?", Journal of Military Chemistry, no. 18/2020, p. 9.

9 Ion Mitulețu, Alexandru Herciu, Apărarea CBRN în operația brigăzii mecanizate, "Carol I" National Defence University, Bucharest, 2014, p. 88.

10 [Presidential administration], The National Security Strategy of Romania for the period 2020-2024, Bucharest, 2020 , p. 8 .

11 Ion Mitulețu, "Are we ready to deal with a biological crisis?", Journal of Military Chemistry, no. 18/2020, p. 9.

\section{REFENCES}

*** Law no. 446/2006 on the preparation of the population for defence.

*** Romanian Government Decision no. 969 of $22^{\text {nd }}$ August 2007 on the organization, conduct and management of training for the defence of 
persons with managerial responsibilities in the field of public administration, at central and local level.

*** CBRN protection Field Manual, Bucharest, 2015.

[Presidential administration], The National Security Strategy of Romania for the period 20202024, Bucharest, 2020.
Mitulețu Ion, "Are we ready to deal with a biological crisis?", Journal of Military Chemistry, no. $18 / 2020$.

Mitulețu Ion, Herciu Alexandru, Apărarea CBRN în operația brigăzii mecanizate, "Carol I" National Defence University, Bucharest, 2014.

https://www.ilo.org/wcmsp5/groups/public 